\title{
CONTRIBUTIONS OF A MATERIALIST ONTOLOGY TO THE CRITICAL KNOWLEDGE OF LABOUR PROCESSES AND WORKERS STRUGGLES
}

\author{
Maria Ceci Misoczky ${ }^{1}$ \\ Rafael Kruter Flores ${ }^{2}$
}

\begin{abstract}
This essay argues that a materialist ontology can contribute to a renewal of the analysis of contemporary labour processes and indicate new possibilities for addressing workers struggles. An ontological/explanatory critique is indispensable to a transformative praxis that confronts the capitalist organization of labour and creates alternatives for the emancipation of labour and humankind. Part of this critique would have to be directed to theory itself, including Labour Process Theory. The main contributions of a materialist ontology in this respect are related to: commodity production inserted in a wider historical context; the overcoming of the subjectivist/objectivist dilemma; labour processes and struggles as open-ended dynamics in which the possibility of freedom always plays a central role; the focus on the qualitative aspects of value (social form), its manifestations and expressions in concrete labour processes and the ways it conditions or determines social relations of production, actions and struggles; the consideration of everyday life and its ontological deep determinants; the analysis of workers organisations and struggles as social exercises of freedom (conscious choices) under structural historically constructed constrains.
\end{abstract}

Key-words: Materialist ontology. Labour Process Theory. Ontological critique. Value. Dialectics.

\section{CONTRIBUIÇÕES DE UMA ONTOLOGIA MATERIALISTA PARA O CONHECIMENTO CRÍTICO DOS PROCESSOS DE TRABALHO E DAS LUTAS DOS TRABALHADORES}

\section{Resumo}

\footnotetext{
${ }^{1}$ Doutora em Administração. Programa de Pós-Graduação em Administração da Universidade Federal do Rio Grande do Sul (PPGA/UFRGS). Correio eletrônico: maria.ceci@ufrgs.br.

${ }^{2}$ Doutor em Administração. Programa de Pós-Graduação em Administração da Universidade Federal do Rio Grande do Sul (PPGA/UFRGS). Correio eletrônico: rafael.flores@ufrgs.br.
}

Revista Brasileira de Estudos Organizacionais . v. 4, n. 2, p. 359-374, dez. 2017, eISSN: 2447-4851 Doi 10.21583/2447-4851.rbeo.2017.v4n2.143

Sociedade Brasileira de Estudos Organizacionais 
Este ensaio argumenta que uma ontologia materialista pode contribuir para renovar as análises de processos de trabalho contemporâneos e indicar novas possibilidades para as das lutas dos trabalhadores. Uma crítica ontológico-explanatória é indispensável para uma práxis transformadora que confronte a organização capitalista do trabalho e crie alternativas para a emancipação do trabalho e da humanidade. Parte desta critica deve ser dirigida à teoria em si, incluindo a Teoria do Processo de Trabalho (Labour Process Theory). As principais contribuições de uma ontologia materialista a este respeito são: a produção de mercadorias inserida em um contexto histórico mais amplo; a superação do dilema subjetivo/objetivo; processos de trabalho e lutas como dinâmicas de final aberto nas quais a possibilidade da liberdade tem papel central; o foco nos aspectos qualitativos do valor (forma social), suas manifestações e expressões em processos de trabalho concretos e as formas pelas quais condiciona ou determina relações sociais de produção, ações e lutas; a consideração da vida cotidiana e seus determinantes ontológicos profundos; a análise de organizações de trabalhadores e lutas como exercícios sociais de liberdade (escolhas conscientes) sob restrições historicamente construídas.

Palavras-chave: Ontologia materialista. Labour Process Theory. Crítica ontológica. Valor. Dialética.

\section{CONTRIBUCIONES DE UNA ONTOLOGÍA MATERIALISTA PARA EL CONOCIMIENTO CRÍTICO CERCA DE LOS PROCESOS DE TRABAJO E DE LAS LUCHAS DE LOS TRABAJADORES}

\section{Resumen}

Este ensayo argumenta que una crítica ontológica materialista puede contribuir para renovar las análisis de procesos de trabajo contemporáneos e indicar nuevas posibilidades para las luchas de los trabajadores. Una crítica ontológico-explicativa es indispensable para una praxis transformadora que confronte la organización capitalista del trabajo y crie alternativas para la emancipación del trabajo y de la humanidad. Parte de esta crítica debe ser dirigida a la teoría en sí misma, incluyendo la Teoría del Proceso del Trabajo (Labour Process Theory). Las principales contribuciones de una ontología materialista en este respecto son: la producción de mercancías insertada en un contexto histórico más amplio; la superación del dilema subjetivo/objetivo; procesos de trabajo y luchas como dinámicas de final abierto en las cuales la posibilidad de la libertad 
tiene rol central; foco en los aspectos cualitativos del valor (forma social), sus manifestaciones y expresiones en procesos de trabajo concretos y las formas por las cuales condiciona o determina relaciones de producción, acciones y luchas; la consideración de la vida cotidiana y sus determinantes ontológicos profundos; la análisis de organizaciones de trabajadores y luchas como ejercicios sociales de libertad (elecciones conscientes) bajo restricciones históricamente construidas.

Palabras-clave: Ontología materialista. Labour Process Theory. Crítica ontológica. Valor. Dialéctica.

This essay argues that a materialist ontology can contribute to a renewal of the analysis of contemporary labour processes and indicate new possibilities for addressing workers struggles. By materialist ontology, we refer to the late work of Lukács (1978a and 1978b) in association with Bhaskar's (1993) work on dialectics ${ }^{3}$. Our aim is not to provide another critique of Labour Process Theory (LPT) ${ }^{4}$, but to introduce the propositions of these two philosophers while presenting how we see their contribution to LPT.

Reading Marx's oeuvre as an ontological critique of capitalism, Lukács (1978a, p. 5), in his late writings, highlights that 'for the first time in the history of philosophy, the categories of economics appear as those of the production and reproduction of human life, and hence make it possible to depict the social existence ontologically on a materialist basis'.

\footnotetext{
${ }^{3}$ Lukács's oeuvre on the ontology of social being had only three chapters published into English (under the titles of Hegel, Marx and Labour). In this paper we worked with the Brazilian complete edition ( 2 volumes) of the Ontology and the Prolegomenon, and consulted two of the English edited material (the translation from the original in German to English is quite poor), namely the books entitled 'Marx' (1978a) and 'Labour' (1978b). Regarding the oeuvre of Bhaskar, we considered only those published before he reoriented his work to a domain unfamiliar with Marxism, closer to mysticism and religious thought.

${ }^{4}$ For an overview of Labour Process Theory origins and contemporary debates, see Thompson (2010) and Thompson and Smith (2010).
}

Revista Brasileira de Estudos Organizacionais . v. 4, n. 2, p. 359-376, dez. 2017, eISSN: 2447-4851 Doi 10.21583/2447-4851.rbeo.2017.v4n2.143

Sociedade Brasileira de Estudos Organizacionais 
Bhaskar (1993, p. 56 and 66) also saw his own dialectical work ${ }^{5}$ as an extension of 'Marx concern with the dialectical explanation and practical transformation', identifying a 'totalising ontology' never fully developed that could be accommodated within critical realism. We are not saying that these two philosophers have similar propositions, we are aware of very important differences between them. Instead, in philosophical terms, we agree with Duayer and Medeiros (2005) argument that Lukács' ontology of the social being could contribute to a renewal of critical realism - despite the lack of interest of those who work within this perspective to explore the mutual benefits of combining both propositions. Of course, to do that is not the aim of this paper. What we do here is merely to explore some complementarities having in mind potential contributions to LPT.

The first and foremost is related to the category of labour. For Lukács (1978a, p. 25), labour is the founding category of the social being because the historical process of development of the latter (from inorganic and organic towards social) involved an ontological transformation: the rise of a new objectivity expressed in the teleological project as a form of material transformation of material reality. Social being, for Lukács, is a 'level of material existence'. Therefore, human practice is finalistic; it is the ideal positing of an end, its consequence is objectification: it is teleological (LUKÁCS, 1978a and 1978b).

Labour - the activity of material reproduction of human beings, 'the original phenomenon', 'the model for all social practice', the exclusively human activity that makes 'teleological positing' real - can illuminate

\footnotetext{
${ }^{5}$ One of his aims is to overcome the limits of his previous proposition of the world as being layered into different domains of reality and the fallibility of knowledge (Bhaskar, 1975). 
CONTRIBUTIONS OF A MATERIALIST ONTOLOGY TO THE CRITICAL KNOWLEDGE OF LABOUR

PROCESSES AND WORKERS STRUGGLES

Maria Ceci Misoczkv I Rafael Kruter Flores

other kinds of social positing (LUKÁCS, 1978b, p. 46) because the teleology entailed in labour is what distinguishes the specific human practice from the reproduction of other forms of being (organic and inorganic). In other words, we can only understand the human being as such if we comprehend that its genesis, its becoming distinct from its natural basis, 'is a function of the continuous realisation of teleological projects', is a reliance upon labour (LUKÁCS, 1970, p. 166). The essence of human labour, for Lukács (1978b), consists firstly on its arising amid the struggle for existence, and secondly on all stages of its development being products of the human beings' own self-activity.

Dorahy (2012, p. 1) highlights that Lukács (1970) emphasises 'the functional role of subjectivity as a constitutive moment in the socialhistorical process', while stating that objective teleology has the property of imbuing reality with meaning, remaining within the purview of its creator. Lukács (1978a, p. 6) draws on Marx (1973), for whom the central question was the production and reproduction of human life and labour the central category, because as labour is a creator of use-value, 'it is a necessary condition for the existence of humankind'. This making useful is a teleological process in which the achieved result 'had already existed in the imagination of the labourer at its commencement'.

Mészáros (2011, p. 36) also stresses Marx's rejection of all forms of 'theological teleology', focusing on the 'dynamic material/intellectual telos of labour: both as human self-production and as the production of the conditions of emancipatory social transformation'. This author supports Lukács' (1978b) propositions of an objective teleology in which 'labour has the function of an active mediation at the progressively changing 
CONTRIBUTIONS OF A MATERIALIST ONTOLOGY TO THE CRITICAL KNOWLEDGE OF LABOUR PROCESSES AND WORKERS STRUGGLES

Maria Ceci Misoczkv I Rafael Kruter Flores

metabolism between humankind and nature'. In this sense, history is conceived as necessarily open-ended.

Lukács (1978a) treats labour as a formal category of social ontology. Therefore, he is not referring to any specific productive/labour process. However, it was the ontological fundament of labour that allowed Marx (1973) to elaborate a radical critique of a concrete historical system, in which the theory of value is central. It also supported Lukács (1978b) proposition that the humanization of man through labour forms the genetic point of departure to freedom. Labour is a causal chain transformed into a posited causality, it involves conscious decisions between alternatives. As 'the original phenomenon', it is also the model for all social practices. It is in this conscious decision that the phenomenon of freedom can be investigated in its ontological genesis. In the first place, because 'the basis of freedom [...] consists in a concrete decision between different concrete possibilities'; in the second, because 'freedom is ultimately a desire to alter reality $[\ldots]$ and in this connection reality must be preserved as the goal of change, even in the most far-reaching abstraction' (LUKÁCS, 1978b, p. 114).

An indispensable aspect of the possibility of freedom in the teleological positing of alternatives to transcend the existing order is the critique of political economy as an ontological critique of the capitalism. In Bhaskar's (1986, p. 121) logic, the explanatory critique provides the knowledge of the (causal) conditions of action, the springs of belief and behaviour, the sources of determination' with the objective of illuminating the transcendence of these sources of determination. For this task, call it ontological or explanatory critique, we need Marx's (1973) theory of value. 
The contemporary dynamics of capitalist development - such as productive restructuration, expansion of services, financialisation or activities' reconfiguration in the context of informational technology may lead to a very fashionable misunderstanding: abstract labour and, consequently, value theory does not make sense any more. However, in Bhaskar (1993, p. 65) words, capitalism is defined by 'an original generative separation, split or alienation of the immediate producers from the means and materials of their production', and this separation persists under contemporary capitalism ${ }^{6}$.

The coherence of capitalism ${ }^{7}$ is achieved through an abstraction of the real process in which emerges the category of value: 'an objectively central category in the ontological sense', 'the central category of social production' that results from a historical process ${ }^{8}$ (LUKÁCS, 1978a, p. 3738). In Marx's (1973, p. 776) words, value 'is the most abstract expression of capital itself and of the production resting in it'. In the interpretation of

\footnotetext{
${ }^{6}$ This fundamental or primary contradiction escapes our understanding if we despise value theory, as Baran and Sweezy (1996, p. 53) did. For these authors, who are so influent on both Braverman (1974) and LPT original works, with the advent of monopolist capitalism, 'market relations are essentially price' and the study of monopoly capitalism 'must begin with the working of the price mechanisms'. They also focus on the 'generation and absorption of surplus', instead of plus-value, resulting in 'almost total neglect of a subject that occupies the central place in Marxist study of capitalism: the labour process' (BARAN and SWEEZY, 1996, p. 8). In this perspective, one could conclude that it doesn't matter what happens in the productive process, how the social relations of production are, what kind of exploitation of labour is achieved, or who controls the means of production and the division of the social product between capital and labour.

${ }^{7}$ It is worth reminding that the existence of a coherent global structure does not mean a homogenous totality. Instead, the system is full of contradictions and has a multiplicity of constituents and divisions. In Marxian terms, 'total social capital' is 'the comprehensive category that incorporates the plurality of capitals, with all their contradictions'. In the same way, the 'totality of labour' cannot be taken as a homogenous entity: 'there are, of necessity, so many contradictions, which you find under the given historical conditions among sections of labour, opposing and fighting one another, competing against one another, rather than simply confronting particular sections of capital' (MÉSZÁROS, 2008, p. 72).

${ }^{8}$ The innovative aspect of Marx's analysis of value is, for Lukács (1978a), the way he deals with abstraction, not as merely metaphysics or a pure theoretical effort, but a means to identify rational nexus of real social processes.
}

Revista Brasileira de Estudos Organizacionais . v. 4, n. 2, p. 359-376, dez. 2017, eISSN: 2447-4851

Doi 10.21583/2447-4851.rbeo.2017.v4n2.143

Sociedade Brasileira de Estudos Organizacionais 
Rubin (1990), value is a social relation among people, which assumes a material form and is related to the process of production.

Following Rubin (1990), it is necessary to confront frequent misunderstandings of the theory of value: it is not confined to exchange relations among things; it is not an analysis of relations between labour and things that are products of labour (here we could include many other commodity forms, such as money, financial expressions, brands etc.). It is about relations among people who are connected to each other through things. The concept of abstract labour as socially necessary labour time (its quantitative aspect) is part of this analysis, since according to Marx's original definition; this is what determines the magnitude of value of a commodity. Nevertheless, value has also a qualitative aspect: it is an expression of the social relations of production among people. It is 'a social form which is acquired by the products of labour in the context of determined production relations among people'. Value is 'a social relation taken as a thing ${ }^{\prime 9}$. The definition of value 'as the expression of production relations among people does not contradict the definition of value as an expression of abstract labour'. The difference is that the first definition of value considered its quantitative aspect (as a magnitude), and the second and last one considered its qualitative aspect (as a social form). Consistently with this, 'abstract labour is now being treated as social labour in its specific form which presupposes production relations among people as commodity producers' (RUBIN, 1980, p. 67-68).

\footnotetext{
9 'We are dealing with a human relation which acquires the form of being a property of things and which is connected with the process of distribution of labour in production. In other words, we are dealing with reified production relations among people. The reification of labour in value is the most important conclusion of the theory of fetishism, which explains the inevitability of "reification" of production relations among people in a commodity economy' (RUBIN, 1990, p. 72). 
Drawing on Bhaskar's (1993) statement that absence can be a reality as much as presence, Arthur (2011, p. 218) treats value as an 'empty presence', as a spectral objectivity that 'prevails over the material of economic life'. As a form without content, this 'ontological vampire', this 'active negativity' is the real expression of its ultimately name: capital (ARTHUR, 2011, p. 121). In Lukács' (1978b) terms, we can refer to the ontonegativity of value: a mediation that empties all vital activity of content and transforms the proper human action into estrangement and alienation.

If the capitalist process of self-valorising value dialectically negates the realm of the concrete labour of production, how can we apprehend it?

An indication comes from Marx (1973). According to him, we should proceed from the totality of the existent, and seek to comprehend this as closely as possible in all its intricate and manifold relationships. In Lukács' (1978a, p. 27) interpretation, totality is a 'complex of partial complexes'. For him, 'the totality is not formal or ideal, and the categories are not building blocks of a hierarchical system, but forms of being, characteristics of existence, elements for the construction of relatively total, real and dynamic complexes, whose reciprocal inter-relations produce ever more comprehensive complexes' (LUKÁCS, 1978a, p. 19). This last quote highlights that even the smallest constituents of a social complex are themselves complexes. Thus, in describing the social totality, 
it is necessary to consider what he calls a complex of complexes ${ }^{10}$, and not the mere combination of isolable constituents.

The consequence of the previous indications is that particular labour processes must be considered as part of the wider complex that is the reproduction of society ${ }^{11}$. However, in a particular study of a specific situation, the relationship between labour and social reproduction can only be understood in a limited form because the singular act never contains the totality of determinants that operate in the universality of which it is a singular. The effort is to have this in mind and study labour processes and the political activity of workers as historically concrete relationships within the social totality, retaining 'the precise separation of the real, as a process that exists in itself, from the ways by which it comes to be known' (LUKÁCS, 1978a, p. 8). The central idea is that reality exists in itself and the investigation of the real existing must keep it in view in every single fact it establishes and in every concrete relationship it reconstructs in thought. Therefore, 'the manner and direction of the abstractions and thoughts experiments are not determined by epistemological or methodological (at least logical) standpoints, but by the thing itself, i. e., the ontological nature of the material question' (LUKÁCS, 1978a, p. 49).

\footnotetext{
${ }^{10}$ In the intercourse of social historical development, the social being develops through complexes, which are characterised by a relative autonomy that cannot be foreseen neither apprehended though logic. Nonetheless, a complex is rational from an ontological social point of view, i.e., 'they can be precisely determined and precisely delimited in methodological-conceptual terms in relation to all other complexes by means of a concrete analysis of their essence and function, their genesis, and eventually the prospect of their extinction or their permanent social performance' (LUKÁCS, 2013, p. 250). Language is the only complex that permeates all the others. Although Lukács (2013) does not intend to provide an extended analysis of the complexes that constitutes society, it is important to retain the fact that, from an ontological point of view, totality must be apprehended through the dialectical movement of a plurality of complexes, which differ from one another and demand particular analysis of its genesis, overlaps, interconnections etc.

${ }^{11}$ Society expresses the totality; it is a complex of complexes in Lukács (1978a) interpretation.
} 
Complementarily, Mészáros (2011, p. 56) explains that following the Marxian conception of totality, every single element of social processes and transformations are considered in its dialectical linkages with all the others. The 'overall complex can be visualized as dialectical only because its "moments" themselves are dynamically interconnected constituents of a structured whole'. In other words, 'there is a fundamental coherence between the global structure and its "microstructures" without which one could only speak of some chaotic aggregate of disparate elements, and not of a developing social totality, with identifiable tendencies of its own'.

Bhaskar (1998, p. xvi) suggests that the grounds for abstraction lie in the 'real stratification and ontological depth' in attempts to grasp 'the generative mechanisms and causal structures which account in all their complex and multiple determinations for the concrete phenomena of human history'. In this, ontological/explanatory critique plays a key role. Needless to state the indispensable and constant presence of dialectics to understand that 'the appearance is not only just as socially existent as the essence, that the two are produced by the same social necessities' and are components of the same social-historical complex.

It is indispensable to specify the concrete complex under study. Specification has also an ontological sense and refers to 'the investigation of the way that particular laws, their concrete expression, variation, tendential form and their particular mode of operation affect specific concrete complexes in specific concrete circumstances' (LUKÁCS, 1978a, p. 106).

The next question is where to look for information that would allow the achievement of these dialectical linkages. Lukács (2012, p. 30) says it 
clearly: everyday life $^{12}$ is the locus from where ontology elevates and to where it must land, if it wants to be effective, 'even if in a simplified, vulgarized and disfigured way'. His ontological concerns are thus defined as being the 'problems of everyday life that emerge under given historical conditions, in existing class situations and in the corresponding attitudes of humanity in the face of a social reality immediately given to itself' (LUKÁCS, 2012, p. 32). However, due to the basic fact that we are never able of having a total knowledge of all the components of our decisions and consequences, at everyday life the real being usually presents itself distorted. The immediate modes of manifestation uncover what is really essential at the ontological plan. Therefore, it is necessary 'to start at everyday life and, at the same time, to move beyond it in order to apprehend the authentic being'. At the same time, the most indispensable means of intellectual apprehension have to be submitted to a permanent critical consideration, taking into consideration the simplest ontological constitution (LUKÁCS, 2010, p. 37).

Another key aspect is the relationship between human activity and social structures. Both Lukács (1978a) and Bhaskar (1993), drawing on Marx (1973, 1976), affirm that agents are always acting in a word of structural constraints and possibilities that they do not produce: 'social structure, then, is both the ever-present condition and the continually reproduced outcome of intentional human agency' (BHASKAR, 1998, p. xvi).

${ }^{12}$ Bhaskar (1993) also refers to 'everyday world' as the space for the analysis of causal mechanisms in its absences and contradictions. 
Mészáros (2011, p. 71) provides a clear illustration of this process, considering the "simultaneously "positive negativity" and "negative positivity" of the historical process in contemporary capitalism. The three major considerations of Mészáros (2011, p. 71-76) are as follows:

(i) The purpose envisaged in the immediacy of the labour process 'can only be a partial one, directly related to the task at hand, even if the cumulative partial solutions are always inserted into an increasingly broader context'. The positivity is defective, because 'it cannot control the global consequences and implications of its own success', which may turn out to be disastrous despite the positivity originally posited. As the multiplicity of limited teleological designs is realized in the course of practical productive activity, 'a "totalization” of some kind takes place'. However, 'it is a "totalization without a totalizer" and therefore the conscious partial projects must suffer the (negative, unintended) consequences of being inserted into a "blind" overall framework that seems to defy any attempt at being controlled'. On one hand, the negative meaning of this circumstance is that the partial positing activities remain more than ever subordinated to the irrationality of the prevailing global determinations. On the other, 'the positive meaning of this objective tendency toward a global integration of the labour process is that it opens the possibility of a conscious control over the social metabolism as a whole'. Nevertheless, of course, 'the historical unfolding of labour's objective teleology creates only the potentiality of a successful control of the conditions of human self-mediation and self-realization'. This potentiality can only be translated into actuality 'through a radical break with the prevailing system of determinations as a result of a conscious 
human enterprise that envisages itself as its own end, in contrast to the present modality of labour's teleology in which the positing activity is dominated by alien ends, from the fetishism of commodity to antagonistic contradictions between states'.

(ii) Another condition is the permanent structural presence of basic material determinations in the changing social metabolism. Although the development of complex needs may displace the realm of bare necessity, it can do so only 'at the cost of activating a new, and far more extensive, order of necessity whose mastery becomes increasingly more difficult within the framework of capital's perverse logic'. Therefore, 'the "positive negativity" and "negative positivity" of open-ended social development can only be pictured in the image of Janus, with one of his two faces pointing in the direction of humanity's triumph, the other confronting in anguish the hell of self-destruction'.

(iii) Any increase in the powers of production is simultaneously also an increase in the powers of destruction. The more extensive and multiform society's needs vis-à-vis nature, 'the greater - and potentially more destructive - the forces that must be constantly activated to secure their satisfaction'. The problems are further aggravated because 'the teleology of both technology and natural science is rooted in the primitive technology of labour, and the original limitations of the latter - the constraining results of the necessary partiality of its positing activity earlier referred to - are reproduced even at the most advanced phase of capitalistic developments'.

This account would sound quite catastrophic if we do not pay attention to Lukács (1978b, p. 114) account of teleology as the open-ended 
possibility of emancipatory social transformation. Only the social being has the possibility of freedom because of its capacity of consciously choosing among alternative goals and defining causal series required for its realizations. This ontological and genetic conception states that the basis of freedom consists in 'a concrete decision between different concrete possibilities' and that freedom is 'ultimately a desire to alter reality'. Therefore, 'reality must be preserved as the goal of change'. The dialectics between determinacy and freedom is at the centre of a social complex in which freedom is determined by necessity; and value (as knowledge) is a general precondition.

After this very brief and introductory explanation of the materialist ontology, we can, also briefly, highlight some of its contributions to advance a critical knowledge of labour processes and workers struggles.

The most evident is that ontological/explanatory critique is indispensable (even if not sufficient) to a transformative praxis that confronts the capitalist organization of labour and creates alternatives for the emancipation of labour and humankind. Part of this critique would have to be directed to theory itself, including LPT.

The main contributions of a materialist ontology to the critical knowledge of labour processes and workers struggles are summarized below.

- To consider labour process as a process in which humans produce usevalues, thus defining through teleology its own social existence; an analysis that presupposes the commodity production but inserts it in the wider historical context. 
- To overcome the subjectivist/objectivist dilemma through the assertion that subjectivity is constitutive of the historical processes whereas the meaning of reality is the result of objective teleology.

- To analyse labour processes and struggles as open-ended dynamics in which the possibility of freedom always plays a central role, as it is present in conscious decisions and in the production of alternatives that characterize teleological positing.

- To investigate the causal conditions of actions (labour processes and/or workers struggles), beliefs and behaviours through the analysis of the wider complex that is the reproduction of society, a totality that achieves coherence through the value form.

- To focus on the qualitative aspects of value (social form), its manifestations and expressions in concrete labour processes and the ways it conditions or determines social relations of production, actions and struggles. This demands to encounter the connections between the particularity of an event or process to the possible determinants (dialectical linkages) of its universality through the creation and innovation of analytical methods and ways of abstracting, following Lukács (1978a, p. 8) warning about the precise separation of the real, as a process that exists in itself, from the ways by which it comes to be known'.

- To interrogate labour processes taking everyday life into consideration, in search of its ontological deep determinants, i.e., to find the concrete, distorted and obliterated relations between social relations of production, under the value social form, in a specific domain and other 
CONTRIBUTIONS OF A MATERIALIST ONTOLOGY TO THE CRITICAL KNOWLEDGE OF LABOUR PROCESSES AND WORKERS STRUGGLES

Maria Ceci Misoczkv I Rafael Kruter Flores

aspects of social life such as leisure, pleasure, spirituality, joy, rules of sociality, history, nature etc. that conforms that domain.

- To analyse workers organisations and struggles as social exercises of freedom (conscious choices) under structural historically constructed constrains.

\section{References}

ARTHUR, C. J. The spectral ontology of value. In: BROWN, A.; FLEETWOOD, S.; ROBERTS, J. (Eds.) Critical Realism and Marxism. London: Routledge, 2011, pp. 215-233.

BARAN, P.; SWEEZY, P. M. Monopoly capital: an essay on the American economy and social order. New York: Monthly Review Press, 1996.

BHASKAR, R. A realist theory of science. London: Verso, 1975. . Scientific realism and human emancipation. London: Routledge, 1986. . Dialectis: the pulse of freedom. London: Verso, 1993. . General introduction. In: ARCHER, M. et al. (Eds.) Critical Realism: essential readings. London: Routledge, 1998, pp. ix-xxiv.

BRAVERMAN, H. Labor and monopoly capital: the degradation of work in the twentieth century. New York: Monthly Review Press, 1974.

DUAYER, M.; MEDEIROS, J.L. Lukács' critical ontology and critical realism. Journal of Critical Realism, n. 2, v. 4, p. 395-425, 2012.

DORAHY, J. F. Lukács and the dialectic of labor. Available at: http://www.telospress.com/lukacs-and-the-dialectic-of-labor/ Dec., 2012. Accessed 17 January 2018.

LUKÁCS, G. The dialectic of labor: beyond casuality and teleology. Telos n. 6 , pp. $162-174,1970$ 
CONTRIBUTIONS OF A MATERIALIST ONTOLOGY TO THE CRITICAL KNOWLEDGE OF LABOUR PROCESSES AND WORKERS STRUGGLES

Maria Ceci Misoczkv| Rafael Kruter Flores

. Marx's basic ontological principles. London: Merlin Press, 1978a. . Labour. London: Merlin Press, 1978b.

. Prolegômenos para uma ontologia do ser social. São Paulo: Boitempo,

2010.

. Para uma ontologia do ser social, v. 1. São Paulo: Boitempo, 2012.

. Para uma ontologia do ser social, v. 2. São Paulo: Boitempo, 2013.

MARX, K. Grundrisse: Outlines of the critique of political economy. London: Penguin, 1973.

Capital. V. I London: Penguin, 1976.

MÉSZÁROS, I. The challenge and burden of historical time: socialism in the Twenty-First Century. New York: Monthly Review Press, 2008.

Social structure and forms of consciousness: the dialectic of structure

and history. V. II. New York: Monthly Review Press, 2011.

RUBIN, I. Essays on Marx's theory of value. Montréal: Black Rose, 1990.

THOMPSON, P. The capitalist labour process: concepts and connections.

Capital and Class, n. 1, v. 34, pp. 7-14, 2010.

THOMPSON, P.; SMITH, C. (eds.) Working Life: Renewing Labour Process

Analysis. London: Palgrave Macmillan, 2010.

Submetido em: 27/02/2018

Aprovado em: 23/03/2018

Revista Brasileira de Estudos Organizacionais . v. 4, n. 2, p. 359-376, dez. 2017, eISSN: 2447-4851

Doi 10.21583/2447-4851.rbeo.2017.v4n2.143

Sociedade Brasileira de Estudos Organizacionais 